\begin{tabular}{|c|c|c|}
\hline Beitr. Ent. & Keltern & ISSN 0005-805X \\
\hline $\mathbf{6 1}(2011) 2$ & S. $371-387$ & 10.11 .2011 \\
\hline
\end{tabular}

\title{
Taxonomy and historical biogeography of the genus Rhyacophila PICteT, 1834 on the Philippines
}

\section{(Insecta, Trichoptera)}

With 30 figures and 3 tables

Wolfram MeY

\section{Zusammenfassung}

Die Gattung Rhyacophila ist auf den Philippinen mit 9 Arten vertreten. Davon werden hier fünf neue Arten beschrieben: $R$. baldensis sp. n., $R$. banahawmontis sp. n., $R$. amoyanensis sp. n., $R$. pilifera sp. n., und $R$. cordilliera sp. n. Die Genitalapparate der Männchen und die Imagines von vier Arten werden abgebildet. Die Arten verteilen sich auf die castanea-Gruppe und die neu aufgestellte spinosellata-Gruppe. Zwei Punktkarten zeigen die Verbreitung der Gruppen auf den Philippinen. Die Verwandtschaftsverhältnisse werden in drei Kladogrammen dargestellt, die auf der Analyse genitalmorphologischer Merkmale beruhen. Die Arten der castanea-Gruppe sind über Borneo auf die Philippinen eingewandert. Die spinosellata-Gruppe ist endemisch auf den Philippinen. Ihre Arten werden als Reliktendemiten angesehen, da die nächsten Verwandten in Ostasien und Japan vorkommen, und die Artengruppe ansonsten in ganz Südostasien fehlt. Die möglichen Ausbreitungsmechanismen werden kurz diskutiert.

\section{Summary}

Nine species of the genus Rhyacophila occur on the Philippines. Five species are described as new: $R$. baldensis sp. n., $R$. banahawmontis sp. n., $R$. amoyanensis sp. n., R. pilifera sp. n., and $R$. cordilliera sp. n. The male genitalia and adults of four species are illustrated. The species belong to two species-groups, with the latter group established herein. The ranges of these groups in the Philippines are depicted in two maps. Phylogenetic relationships were analysed and are presented in three cladograms based on morphological characters of male genitalia. The species of the castanea-group immigrated into the Philippines via Borneo, whereas the species of the spinosellata-group are relict elements of an older Asian fauna. A dispersal scenario is proposed for both groups concerning the colonisation of the Philippines.

Key words

Insecta, Trichoptera, Rhyacophila Pictet, new species, taxonomy, phylogeny, historical biogeography, dispersal scenario, Borneo, the Philippines

\section{Introduction}

The Rhyacophilidae and its large genus Rhyacophila PiCTET, 1834 represent one of the most ancestral branches within Trichoptera. The group has retained many primitive characters especially in wing venation and genital architecture. According to the fossil record the genus is at least Eocene in age, and probably much older (Ulmer 1912, MeY 1988, Wichard et al. 2009). Since most of the Philippine Islands originated only in the Miocene (Hall 1996) the existence of the genus 
predates the formation of this archipelago. The presently known Rhyacophila species on the islands are the result of colonisation processes which started as soon as the islands appeared from the sea. The colonisation history, however, seems to be very complex. It is closely connected with the complicated and puzzling development of maritime South East Asia, including Taiwan, Sundaland and Sulawesi. The Trichoptera fauna of the past was surely as dynamic as it is today. The presentday pattern of its composition and distribution in the area is the result of dispersal, vicariance and subsequent evolution, with dispersal as the principal process in an oceanic environment (CowIE \& Holland 2006). These processes are more or less imprinted in the distribution pattern in the archipelago, and their analyses could possibly enable the reconstruction of their colonisation history. The genus Rhyacophila appears to be a promising candidate for undertaking such an analysis. The quality of the study depends on the available data. A comprehensive inventory and an advanced level of faunistic research could provide the necessary facts. Both information sources are, however, weakly developed in the Philippines. Present knowledge is inadaquate, and we know only parts of the fauna, which are but large enough to recognise the presence of a diverse fauna with a high percentage of endemism. This poor faunistic and taxonomic basis prompted the author to perform a series of field trips to the Philippines from 1994 to 2001. Samples of caddisflies were taken on all major islands. This material forms the principal basis of the present study.

In the 1990s the environmental devastation of large stretches of rainforests and rivers on the Philippines was already at an advanced stage. Many visited areas were devoid of suitable habitats for stenoecious caddisflies and already possessed an impoverished fauna. An unknown number of Rhyacophila populations and probably even endemic species must surely have gone extinct. By now it is no longer possible to achieve a substantial survey of the original distribution of species and communities. The fauna is much reduced and consequently the collected data, although considerable, cannot be significantly increased. Any faunistic or biogeographic research in the Philippines today is actually the study of a fragment out of a fragment. Devastation processes go on in all parts of the country (Broad \& Cavanagh 1993, Heaney \& Regalado 1998). Nearly 20 years ago WiLson (1992) wrote: "Today the Philippine fauna stands on the eve of comprehensive destruction caused by deforestation and the poverty of an increasing human population." The eve is over. The loss of Philippine diversity is now a reality. Nevertheless, the study of the fauna remains an urgent task, at least to recover the information that still can be saved.

\section{Material and methods}

\section{Collecting:}

Adult caddisflies were collected using light. Usually, a light-tower (with 2 superactinic tubes, $12 \mathrm{~W}$ ) was placed in the vicinity of rivers, and the arriving caddisflies were picked up from the gauze sheet that surrounds the tubes. Collecting usually started at sunset and was finished after 3-4 hours. The collected specimens were partly put in $75 \%$ alcohol and partially pinned the next day. During daytime, specimens were captured using a hand-net in the bank vegetation.

\section{Genital preparations:}

The abdomen was boiled in $\mathrm{KOH}$ for some minutes to macerate the muscles, body fat and internal, unsclerotised structures. The abdomens were stained with Chlorazol Black after which the preparation was washed in $70 \%$ ethanol. At this point the abdomen was studied in detail. It was turned in all directions in order to understand the shape and position of its individual components, and all the relevant abdominal and genital structures were now drawn in dorsal, ventral, 
lateral and/or caudal view. A drawing tube attachment to the binocular microscope (LeICA, Wild M8) was used. After study the genitalia were deposited in polyethylene genitalia vials (BIoQUiP Products) filled with glycerin. The vials were attached to the pin.

\section{Deposition:}

Most of the material was preliminarily stored in the Museum für Naturkunde Berlin. Individuals of all species, including paratypes, are to be deposited later in a museum in the Philippines.

\section{Abbreviation of depositories:}

MFN

USNM

\section{Museum für Naturkunde, Berlin}

National Museum of Natural History, Smithsonian Institution, Washington

\section{Results}

\section{1. Taxonomy}

Check-list of Rhyacophila species from the Philippines

$R$. castanea-group

$\begin{array}{ll}R . \text { davao Ross, } 1950 & \text { Mindanao } \\ R . \text { negrosana Mey, } 1998 & \text { Negros } \\ R . \text { banahawmontis sp. n. } & \text { southern Luzon } \\ \text { R. baldensis sp. n. } & \text { northern Luzon }\end{array}$

R. spinosellata-group

R. cataractae MEY, 1998

R. spinosellata MEY, 1994

Negros

R. tenebrosa MeY, 1998

Mindoro

$R$. amoyanensis sp. $\mathrm{n}$.

$R$. pilifera sp. n.

$R$. cordilliera sp. n.

Mindanao

Palawan

southern Luzon

northern Luzon

\section{Description of new species}

\section{R. castanea - group}

\section{Rhyacophila baldensis sp. nov.}

(Figs 1-3, 21)

Holotypus $\sigma^{\star}$, Philippines, Luzon, Mountain Province, village Chatol, $2100 \mathrm{~m}, 17^{\circ} 02 \mathrm{~N}$ $121^{\circ} 03$ E, 16. - 18.11.1997, leg. W. Mey \& K. Ebert (MFN).

Paratypes: $2 o^{\star} \sigma^{\star}$, Luzon, Nueva Viscaya, Santa Fé, Bald Mountains, 1150 m, 11. - 13.11.1997, leg. W. Mey \& K. Ebert (MFN); $2 o^{\star} o^{\star}$, Luzon, Mountain Province, Barlig, $17^{\circ} 03 \mathrm{~N} 121^{\circ} 04 \mathrm{E}$ 1650 m, 14. - 15.11.1997, leg. W. Mey \& K. Ebert (MFN); 1 ơ $^{\star}$, Luzon, Ifugao, Mount Polis, $2000 \mathrm{~m}, 17^{\circ} 01.55 \mathrm{~N} 121^{\circ} 02.48 \mathrm{E}, 13.11 .1997$, leg. W. Mey \& K. Ebert (MFN). 


\section{Derivatio nominis:}

The species is named after the Bald Mountains, south of the Central Cordilliera, where R. baldensis sp. n. was collected the first time.

Length of forewing $6-6.5 \mathrm{~mm}$, wing-span $13-14 \mathrm{~mm}$; head and thorax dark brown; antenna brown, the basal third yellow-brown; ocelli white; forewings dark brown with numerous small white spots scattered over the whole forewing; basal parts of veins with erected, black bristles; fork 4 in forewing as long or longer than its stalk; hindwings pale brown; abdomen black dorsally; abdominal segment VII with short sternal process.

Male genitalia (Figs 1-3): Segment IX forms a complete ring with tergal part large and sternal part much narrower and constricted on the latero-ventral sides; segment X narrow and compact arranged in dorso-lateral position, dorsal side elevated, rectangular in dorsal view, caudal side with broad tooth directed ventrad; anal sclerites large, curved ventrad and with short root; apical band of segment X short, connected basally with the long tergal strap produced distally in short protruding process; coxopodite of inferior appendages angulated ventrally, with long and slender basal apodemes articulating with dorsal base of the phallotheca; ventral lobe of harpago elongate; phallic apparatus long, aedeagal complex with short dorsal process and broad, membranous ventral plate; ventral plate shortly excised apically, small and slender lateral lobes present; para-
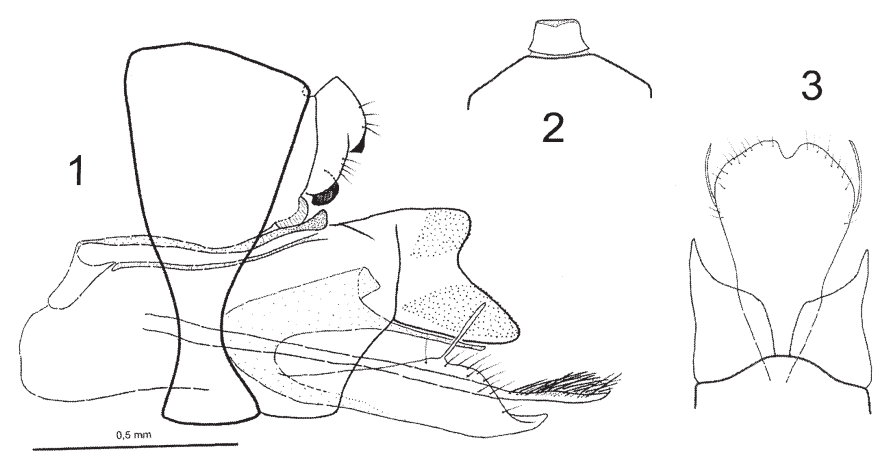

meres long, crossing each other and bearing numerous bristles on the clubbed ends.

\section{Remarks:}

Rhyacophila baldensis sp. $n$. is a member of the castanea-group.

It stands close to the other Philippine species of the group by a similar structure of segment $\mathrm{X}$. The form
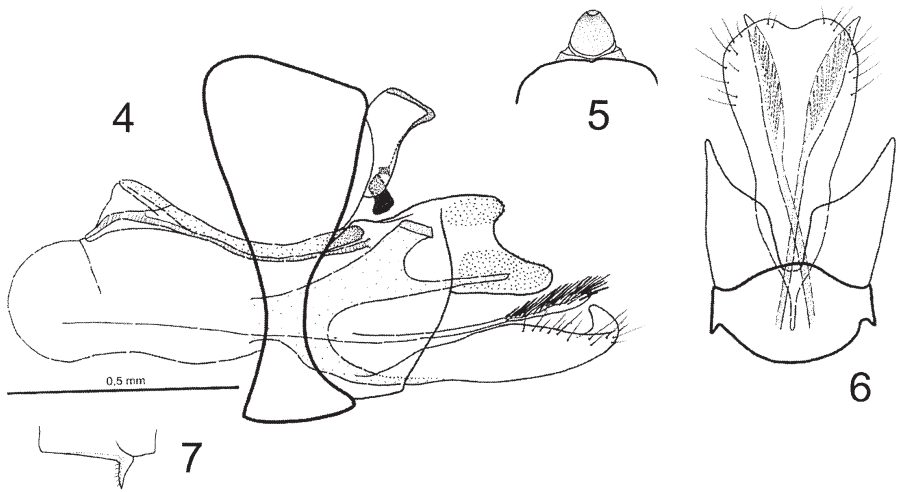
of the inferior appendages and the dorsal aspect of segment $\mathrm{X}$ provide the distinguishing features for separating the new species from its relatives.

Figs 1-7: Male genitalia, Rhyacophila baldensis sp. n., 1 - lateral view, 2 - dorsal view, 3 - ventral view with ventral plate of aedeagus; Rhyacophila banahawmontis sp. n., 4 - lateral view, 5 - dorsal view, 6 - ventral view with ventral plate of aedeagus, 7 - ventral process of segment VII. 


\section{Rhyacophila banahawmontis sp. $\mathbf{n}$.}

(Figs 4-7, 22)

Holotype, $0^{*}$, Philippines, Luzon, Quezon, Mount Banahaw, Dolores, Kinabuhayan, $800 \mathrm{~m}$, Cristal Falls, $14^{\circ} 02.11$ N $121^{\circ} 27.02$ E, 17. - 19.3.2000, W. Mey, K. Ebert \& V. Richter (MFN).

Paratypes: $2 o^{\star} o^{\star}, 3$ 우 우, same data as holotype (MFN).

\section{Derivatio nominis:}

The specific epithet is derived from the name of the terra typica, the lower elevations of Mount Banahaw in southern Luzon.

Length of forewing 5.5 - 6 mm, wing-span $11-12 \mathrm{~mm}$; head and thorax dark brown; antenna brown, the basal third yellow-brown; ocelli white; forewings dark brown with numerous small white spots scattered over the whole forewing, especially dense in costal area; basal parts of veins with erected, black bristles; fork 4 in forewing as long or longer than its stalk; hindwings pale brown; abdominal segment VII with short sternal process.

Male genitalia (Figs 4-7): Segment IX complete ring with tergal part large and sternal part much narrower, constricted on the latero-ventral sides; segment $\mathrm{X}$ narrow and compact arranged in dorso-lateral position, dorsal side elevated, but flat and oval in dorsal view, caudal side without lateral teeth; anal sclerites moderately large, curved ventrad and with short root; apical band of segment $\mathrm{X}$ inconspicuous, connected basally with the long tergal strap which is produced distally in a short, freely protruding process; coxopodite of inferior appendages angulated ventrally and with long and slender basal apodemes articulating with dorsal base of phallotheca; ventral lobe of harpago elongate, rounded apically; phallic apparatus long, aedeagal complex with broad dorsal process and wide, membranous ventral plate; ventral plate shortly up-curved apically, lateral lobes absent; parameres long, crossing each other and bearing 6-8 bristles on the clubbed tips.

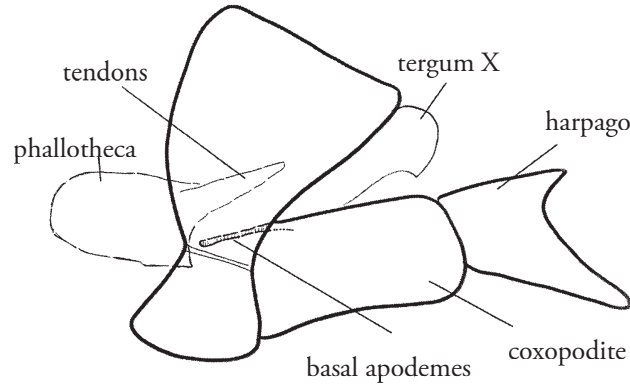

Fig. 8: Simplified sketch of male genitalia of Rhyacophila.

\section{Remarks:}

Rhyacophila banahawmontis sp. $\mathrm{n}$. is a member of the castanea-group. It is obviously related to $R$. negrosana Mey, 1998. Both species lack the lateral lobes of the ventral plate of the aedeagal process.

\section{Rhyacophila spinosellata - group}

The group is established here to accommodate the following three new species and two previously known species. The latter species were assigned by MeY (1999) to a basal position within the yosiiana-group. The study of the new species revealed two synapomorphic characters (rectangular, plate-like dorsal process of phallotheca and large, un-rooted anal sclerites) which exclude the species from the yosiiana-group and necessitate the establishment of a group in its own. All included species are endemic to the Philippines. 


\section{Diagnostic characters of the group:}

- apodeme of coxopodite (= clasper tendon) not articulating with phallotheca (Fig. 9),

- pair of dorsal apodeme of phallotheca joining apical tergal strap (u-shaped piece),

- aedeagus tubular, without ventral or dorsal processes,

- median side of harpago sometimes with hooks or appendages,

- anal sclerites large, paired and without roots,

- rectangular, plate-like dorsal process of phallotheca,

\section{Rhyacophila amoyanensis sp. nov.}

(Figs 10-12)

Holotype o , Philippines, Palawan, Litso, Amoyan Creek, 10 m, 57 km north of Puerto Princesa, 10.12.1965, leg. D. Davis (USNM).

\section{Derivatio nominis:}

The specific epithet is derived from the name of the small river, where the new species was collected.

Length of forewing $5.5 \mathrm{~mm}$, wing-span $12 \mathrm{~mm}$; head and thorax dark brown; frons and setal warts paler, vestiture black; ocelli white; forewings brown with darker pterostigma; legs light brown, spurs black; abdominal segment VII with short sternal process.

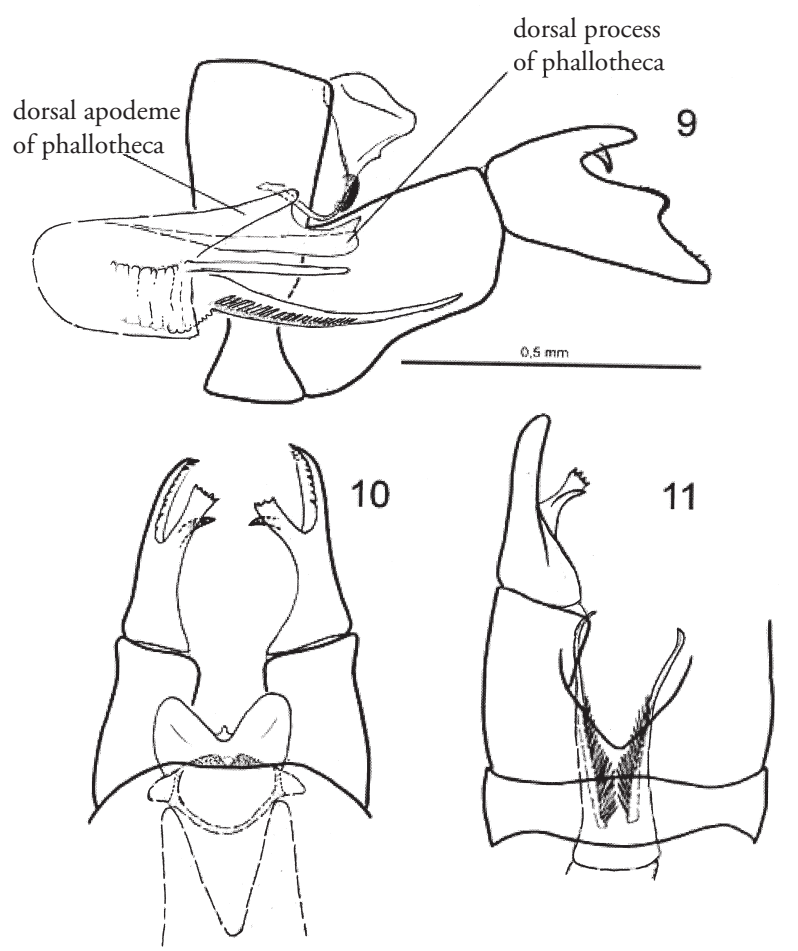

Figs 9-11: Male genitalia of Rhyacophila amoyanensis sp. n., 9 - lateral view, 10 - dorsal view, 11 - ventral view.
Male genitalia (Figs 10-12): Segment IX forms complete ring with tergal part large and sternal part much narrower, both indistinctly separated by short suture on the latero-ventral side; segment $\mathrm{X}$ arranged in dorso-lateral position, dorsal portion deeply excised forming two rounded lobes in dorsal view, lateral flanges with small tooth; anal sclerites moderately large, separated and without root; apical band of segment $\mathrm{X}$ fused basally and articulating with paired tendons of phallotheca; tergal strap absent; dorsal process of phallotheca produced distally in broad, freely protruding process; coxopodite of inferior appendages with slightly concave ventral margin and with slender basal apodemes probably articulating with lateral suture of segment IX by un-sclerotised membrane; ventral lobe of harpago elongate, with row of small teeth on dorsal margin, dorsal lobe short, 
truncate apically and with strong ventro-medially directed process; phallic apparatus short, aedeagus simple, slender tube without dorsal or ventral plates; parameres long, bearing row of black bristles along basal half.

\section{Remarks:}

$R$. amoyanensis $\mathrm{sp} . \mathrm{n}$. belongs to the spinosellata group. It differs from all other members of the group by the basally fused apical band of segment X (= u-shaped piece), the conspicuously shaped harpago and the long parameres.

\section{Rhyacophila pilifera sp. n.}

(Figs 13-17, 23)

Holotype $0^{\star}$, Philippines, Luzon, Quezon, Mount. Banahaw, Dolores, Kinabuhayan, 800-900 m, Cristal Falls and Suplina Falls, $14^{\circ} 02.11$ N 121 27.02 E 17. - 19.3.2000, W. Mey, K. Ebert \& V. Richter (MFN).

Paratypes: $3 \sigma^{\top} \sigma^{\star}$, same data as holotype (MFN).

\section{Derivatio nominis:}

The specific epithet is composed of the Latin words "pilus" (hair) and "fer" (carry) referring to the tuft of long hairs on the harpago.

Length of forewing $6 \mathrm{~mm}$, wing-span $13 \mathrm{~mm}$; head and thorax brown, frons and setal warts pale brown; vestiture on head black; ocelli white; antenna brown; forewings pale brown with darker pterostigma; fork 4 in forewing shorter than its stalk; in anal field of hindwing crossvein Cu2-A1 oblique; legs light brown, spurs black; abdominal segment VII with short sternal process.

Male genitalia (Figs 1317): Segment IX forms complete ring with tergal part large and sternal part much narrower,
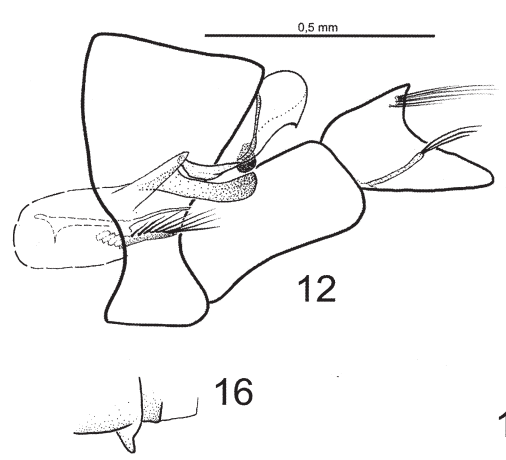

16
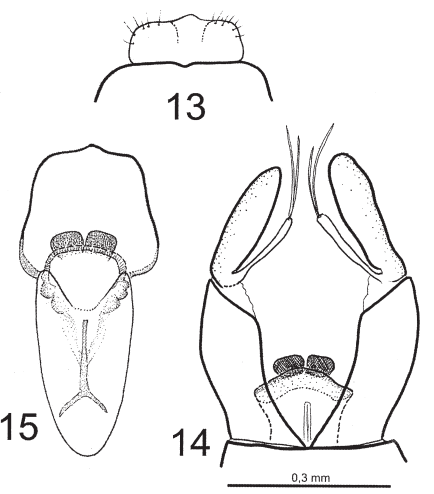

18
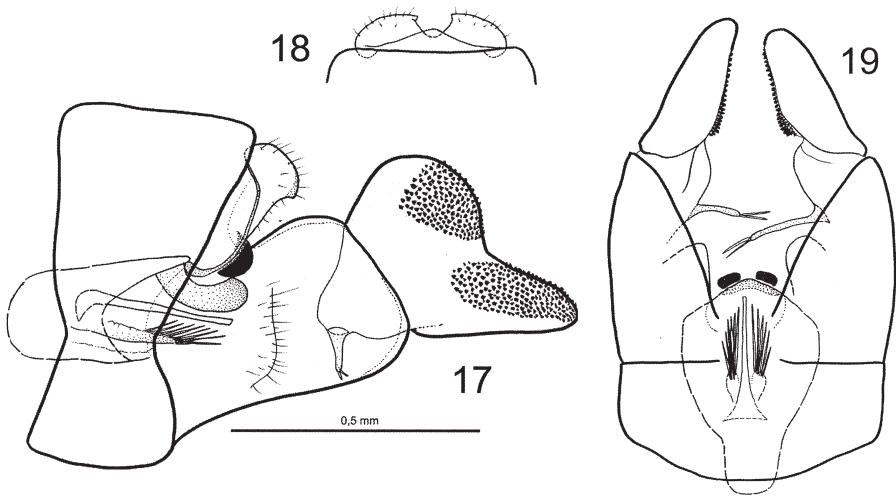

Figs 12-19: Male genitalia, Rhyacophila pilifera sp. n., 12 - lateral view, 13 dorsal view, 14 - ventral view, 15 - phallotheca and segment $\mathrm{X}$ in dorsal view, 16 - ventral process of segment VII; Rhyacophila cordilliera sp. n., 17 - lateral view, 18 - dorsal view, 19 - ventral view. 
both indistinctly separated by a short suture on the latero-ventral side; segment $\mathrm{X}$ arranged in dorso-lateral position, dorsal portion compact with short medial process in dorsal view, lateral flanges with small tooth; anal sclerites moderately large, separated and without root; apical band of segment X separated basally and articulating only with paired tendons of the phallotheca; tergal strap absent; dorsal process of phallotheca produced distally in a broad, freely protruding process; coxopodite of inferior appendages with slightly concave ventral margin and with slender basal apodemes articulating with lateral suture of segment IX; ventral lobe of harpago elongate, with a filiform appendage originating from medial base and running in distal direction, its apex with 2-3 long bristles; dorsal lobe short, with a conspicuous tuft of long hairs on inner side; phallic apparatus short, aedeagus a simple, slender tube without dorsal or ventral plates; parameres short, bearing 8-10 black bristles.

\section{Remarks:}

Rhyacophila pilifera sp. $\mathrm{n}$. belongs to the spinosellata - group. It differs from all other members of the group by the hair tuft of the harpago. It is related to the following species by the common presence of harpagal appendages.

\section{Rhyacophila cordilliera sp. n.}

(Figs 18-20, 24)

Holotype ${ }^{\star}$, Philippines, Luzon, Ifugao, Mt. Polis, 2000 m, 13.11.1997, leg. W. Mey, K. Ebert $\&$ M. Nuss (MFN).

Paratypes: $3 o^{\star} o^{\star}$, Luzon, Benguet, Kabayan, Mount Tabayoc, 2300 m, $16^{\circ} 39$ N $120^{\circ} 55$ E, 22.25.11.1997 (MFN).

\section{Derivatio nominis:}

The species is named after its range in the large mountain chain in northern Luzon which is known as Central Cordillera.

Length of forewing $7-7.5 \mathrm{~mm}$, wing-span $15-16 \mathrm{~mm}$; head and antennae dark brown; setal warts pale brown; thorax black on dorsal side; forewings brown with darker pterostigma; fork 4 in forewing shorter than its stalk; in anal field of hindwing crossvein $\mathrm{Cu} 2-\mathrm{A} 1$ oblique; legs light brown, spurs black; abdominal segment VII with short sternal process.

Male genitalia (Figs 18-20): Segment IX forms complete ring with tergal part large and sternal part much narrower, both indistinctly separated by short suture on the latero-ventral side; segment $\mathrm{X}$ arranged in dorso-lateral position, dorsal portion divided into a pair of bulbous parts, each with short, ventrally directed tooth; lateral flanges thin; anal sclerites large, separated and without root; apical band of segment $\mathrm{X}$ very short, separated basally and articulating only with paired tendons of phallotheca; tergal strap absent; dorsal process of phallotheca produced distally in broad, freely protruding process; coxopodite of inferior appendages with slightly concave ventral margin, a median flat lobe and with slender basal apodemes articulating with lateral suture of segment IX; lobes of harpago rounded, medial sides each with a patch of short, black spines; filiform appendage of harpago originating from medial base and running in medio-ventral direction, its apex with 2 short spines; phallic apparatus short, aedeagus a simple, slender tube without dorsal or ventral plates but with broader base; parameres short, bearing 6-8 black bristles. 


\section{Remarks:}

$R$. cordilliera sp. n. belongs to the spinosellata group. It differs from all other members of the group by the large and compact harpago in the male genitalia with two patches of strong, short spines on the inner side. It is related to the preceding species by the common presence of harpagal appendages on the ventral base.

\section{2. Phylogeny}

The Philippines are a very diverse archipelago in terms of vegetation, climate, island sizes and topograpy. The great variety of available habitats is an ideal situation for arriving immigrants to survive and to settle permanently. The climatic cycles of the last 2 Mio years resulted in a repeated change of vegetation, shifting of vegetation zones and oscillations of island sizes. With each cycle species dispersed, extended and reduced their ranges or became isolated. These processes triggered speciation events and resulted in the formation of a wide spectrum of descendants ranging from simple species pairs to a multiplication of species. In Trichoptera the hamifera - group of the genus Hydropsyche PICTET is an example for the evolution of a large species swarm with more than 20 species distributed over the entire archipelago (Mey 2003). In contrast to Hydropsyche, species of Rhyacophila are ecologically more restricted, more localised and usually occur in smaller numbers. Although more species doubtlessly occur in the Philippines, but escaped collecting so far, the genus has not developed an adaptive radiation like Hydropsyche, with many species occurring in the same river system. Small headwater streams and spring areas remain the habitats of Rhyacophila species as on Borneo. Nevertheless, Rhyacophila exhibits a radiation, but of a different type. This radiation type is characterised by a pool of related species, each of them restricted or endemic to a single island. Congeneric species may occur sympatrically but in these cases they belong to different species groups. It is an open question, whether the species live only on the larger islands or also on smaller ones This would determine the size of the radiation. The Philippine species are distributed between two species groups. These are not closely related (Ross 1956, ScHmid 1970)and are treated here separately:

The castanea-group contains four species which occur on three islands. The morphological analysis revealed that they are descendants of a single ancestor (Tab. 1, Fig. 25) that obviously immigrated from Borneo.

The spinosellata-group, established as new earlier in this paper, contains six species on five islands. In contrast to the castanea group it can be divided into three clades, which are morphologically well differentiated (Tab. 2, Fig. 26). Their ranges in the Philippines do not overlap. This supports the idea that the origin of these species is based on an old, perhaps Miocene colonisation and subsequent diversification. Alternatively, two or three independent colonisation processes could have caused the observed pattern. According to male genital characters the group is related to the yosiiana- and betteni-groups (Tab. 3, Fig. 27). The distribution of the former encompasses the Japanese Islands and the adjacent continental area (Fig. 31). The range of the latter group is confined to western North America.

\subsection{Biogeography}

Biogeographical research in the Philippines has to consider the biology and the ecological requirements of the studied taxa. On this basis two questions have to be answered: Where did the species come from or where did the group originate, and how did they manage to cross the sea? 
Rhyacophila is a large genus encompassing today more than 550 species. It has a predominantly Holarctic distribution. The Himalayan Region is home of a large number of species and species groups and can be considered their diversity centre (Schmid 1989). From this region the numbers are declining towards South East Asia and Sundaland. Beyond Sulawesi, the genus is not known to occur (Mey 1999).

The aquatic larvae of nearly all known Rhyacophila species are free-living predators in running waters. They have a clear preference for temperate and cold streams. Accordingly, the majority of species dwell in the headwaters of rivers in mountain ranges from low to highest elevations. A few species, those of the Philippine included, have adapted to live in springs or spring areas. In the Philippines this habitat-type is not restricted to mountains but occurs in lowlands too. They are often associated with the drainage systems of lowland streams. Rhyacophila species have conquered this biotope and thus can occur outside mountain ranges. Within the Philippines localities of Rhyacophila are distributed from near sea level $(10 \mathrm{~m})$ to over $2000 \mathrm{~m}$. In consequence, their potential distribution on the islands is much wider than the mountain zone and may encompass the entire area of an island. On Borneo the observed altitudinal gradient ranges from $200 \mathrm{~m}$ to over $3000 \mathrm{~m}$ above sea level (cf. Huisman \& Armitage 2011, Mey 2010). It may well be that suitable habitats in the lowlands are populated too, but those areas have largely been transformed into cultural land and human settlements, and suffered a loss of natural habitats such as springs or small streams. Historical or current records of occurring species are absent.

Adults are active during the day. They live in the lower vegetation of river banks as well as in the canopy layer. They are attracted to light, if a light source is in close vicinity to their habitats. According to

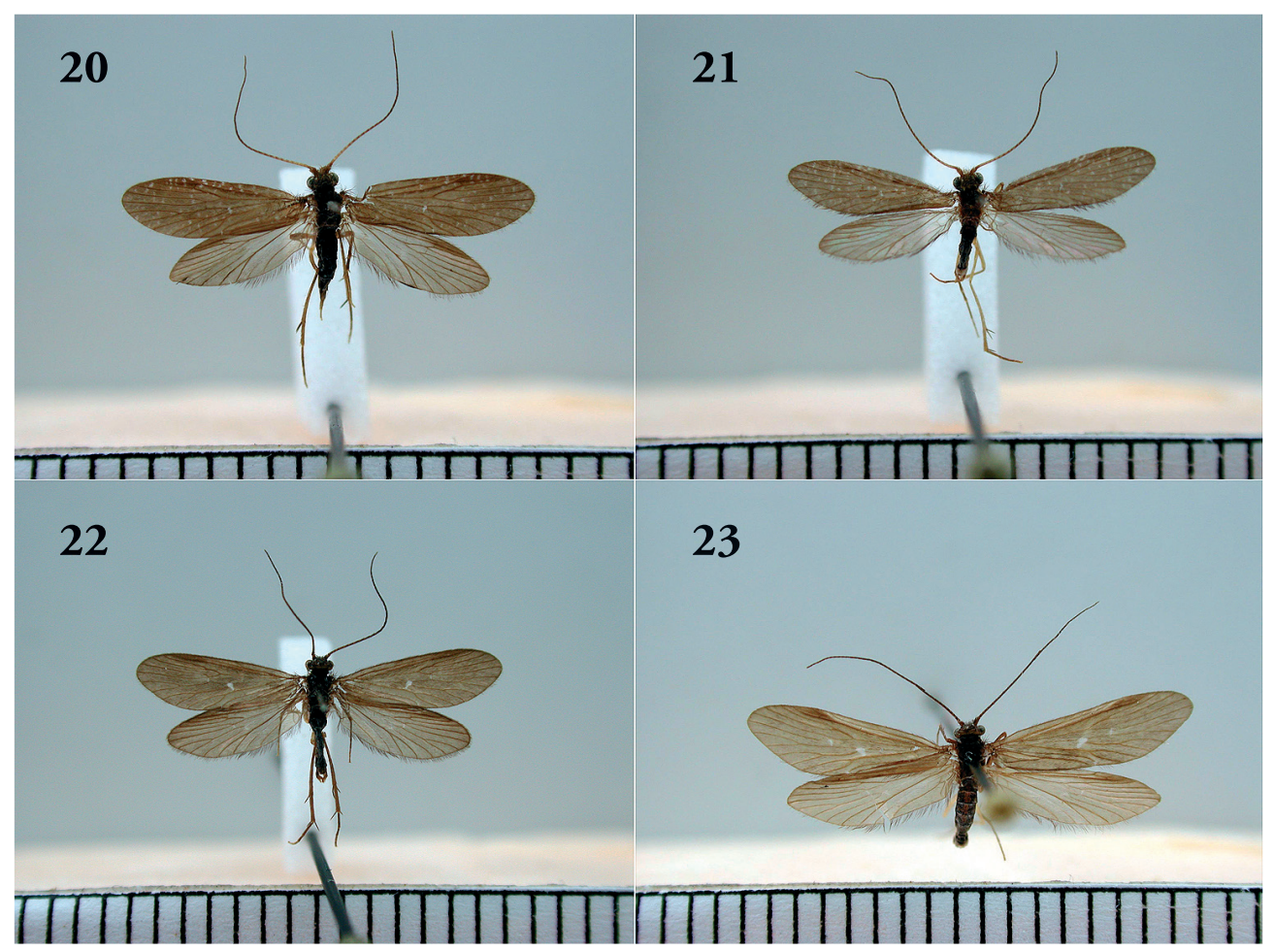

Figs 20-23: Adults of Rhyacophila, $20-R$. baldensis sp. n., female paratype, $21-R$. banahawmontis sp. n., male paratype, $22-R$. pilifera sp. n., male paratype, $23-R$. cordilliera sp. n., male paratype. 
personal observations the adults are weak flyers and only fly for short distances. The body is soft and not as well sclerotised as in temperate species. Thus, the imagines are prone of desiccation. When stored in glass vials they can survive half a day. The dispersal abilities of the adults appear to be poor. They cannot survive in open and sunny places and remain close to the waters where their larvae live. Within the forest, dispersal flights may happen along the streams and its ramifications, and at higher elevations between different water catchment areas. Mountain ridges do not represent serious barriers. The probability of successful migration between isolated forest patches separated by cultivated land, grassland or savanna is expected to be rather low. Adults of aquatic insects have different flight behaviours and dispersal abilities, but it is generally limited (Kovats et al. 1996). Active dispersal of flying Rhyacophila adults over sea straits to reach distant islands can be largely excluded.

It is still a matter of debate, whether the small continental terranes (e. g. the Zamboanga Peninsula, Mindoro Island) were permanently sub-aerial or not (TAN et al. 1988, DE Jong \& TrEadAway 1993, Hall 1996). They are considered here as oceanic islands. All colonisation of the Philippine Islands except the Palawan and Busuanga Islands, which lies on the Sunda-Shelf, must have occurred by over water dispersal in a kind of passive transport. The often discussed rafts of tangled vegetation, carried to the sea by rivers in flood and drifting away to other islands, was a mechanism that could also have carried caddisflies. Floating islands of vegetation are often invoked as mechanism that permitted the dispersal of larger animals including mammals (Wallace 1880, Smith 2001).

During the Quarternary the climate was characterised by cycles of humid and dry periods. Humid periods with more extensive rainforest correlated with periods of high sea level and wider sea gaps. In dry periods, when sea gaps were at their narrowest, rainforests shrank to smaller patches and vegetation of the exposed Sunda shelf was dominated by savanna and grassland (Oosterzee 1997, Morley 2000). The then existing land bridges were of great significance for dispersal for savanna rather than for rainforest species. However, dense forest must have been present along streams and could have served as dispersal corridors. Rhyacophila species of lowland streams and springs could surely survive and disperse in this ecosystem. The expanded mega-islands, which appeared at times of low sea level, allowed dispersion to new areas and mountain ranges that later on became islands again. They also shortened the gaps between islands considerably and formed landbridge-like corridors along the modern Sulu Archipelago, bridging Borneo and Mindanao (HeAney 1985). But even at times of lowest sea level it remained a chain of neighbouring islands. The final crossing of narrow sea straits or sea surfaces probably happened by passive air transport. In the course of tropical thunderstorms and typhoons insects can be lifted to high altitudes, and are carried away by air currents. They are capable of transporting insect specimens over long distances. Each year in the summer months typhoons coming from the Caroline Basin of the West Pacific and running along the west coast of Mindanao and Luzon towards Taiwan or the Asian continent are recurrent events that affect, more or less strongly, the entire Philippine Islands. They have the potential to be important drivers of insect dispersal by passive transport and probably responsible for most of the colonisation processes that happen to occur in all groups of insects, including Trichoptera and Rhyacophila species.

Rhyacophila is represented in the Philippines by only two species groups, the castanea - and spinosellata groups, whereas four and five species groups including the castanea-group occur on Borneo and Sundaland respectively (MeY 1999, 2010). With nine species the curvata-group is the largest group in Borneo. Interestingly, the group has not been reported from the Philippines. Although there are some curvata - group species, dwelling in lowland streams in northern Borneo (e.g. R. tawauensis MeY, 2010) and therefore capable of dispersing in lowland areas, no species of the group has apparently arrived in the Philippines. It would not come as a surprise, were a member of the group to be eventually found in Mindanao. 
Tab. 1: Short description of relevant, male genital character states of the $R$. castanea group in the Philippines.

\begin{tabular}{|c|l|l|}
\hline \multicolumn{3}{|c|}{ character } \\
\hline number & \multicolumn{1}{|c|}{ apomorphic state } & \multicolumn{1}{c|}{ plesiomorphic state } \\
\hline 1 & $\begin{array}{l}\text { lateral appendages of ventral lobe of aedea- } \\
\text { gus reduced in size, ribbon-like or absent }\end{array}$ & $\begin{array}{l}\text { lateral appendages with slender stalk and broad } \\
\text { apical half (dorsal view) }\end{array}$ \\
\hline 2 & $\begin{array}{l}\text { segment X compact in dorsal view, lateral } \\
\text { flanges not prominent }\end{array}$ & $\begin{array}{l}\text { segment X notched in dorsal and caudal view, } \\
\text { lateral flanges prominent }\end{array}$ \\
\hline 3 & $\begin{array}{l}\text { lateral appendages of ventral lobe of aedea- } \\
\text { gus absent }\end{array}$ & $\begin{array}{l}\text { lateral appendages of ventral lobe of aedeagus } \\
\text { present, but thin }\end{array}$ \\
\hline
\end{tabular}

Tab. 2: Short description of relevant, male genital character states of the $R$. spinosellata group in the Philippines.

\begin{tabular}{|c|l|l|}
\hline \multicolumn{3}{|c|}{ Character states } \\
\hline number & \multicolumn{1}{|c|}{ apomorphic } & \multicolumn{1}{c|}{ plesiomorphic } \\
\hline 1 & $\begin{array}{l}\text { Dorsal process of phallotheca broad and } \\
\text { plate-like, fused basally with the phallothe- } \\
\text { cal, dorsal apodemes }\end{array}$ & $\begin{array}{l}\text { Dorsal process a slender extension of dorsal } \\
\text { roof of phallotheca }\end{array}$ \\
\hline 2 & Anal sclerites separate, without roots & Anal sclerites with roots \\
\hline 3 & $\begin{array}{l}\text { length of parameres shortened and with } \\
\text { bundle of apical bristles }\end{array}$ & $\begin{array}{l}\text { Paramers long, with bristles along median side, } \\
\text { apex acute without bristles }\end{array}$ \\
\hline 4 & $\begin{array}{l}\text { Harpago with appendage on inner side } \\
\text { bearing 2 apical spines }\end{array}$ & Harpago without appendage on inner side \\
\hline
\end{tabular}

Tab. 3: Short description of relevant, male genital character states of the $R$. spinosellata, $R$. yosiiana and R. bettenei groups.

\begin{tabular}{|c|l|l|}
\hline \multicolumn{3}{|c|}{ Character states } \\
\hline number & \multicolumn{1}{|c|}{ apomorphic } & \multicolumn{1}{|c|}{ plesiomorphic } \\
\hline 1 & $\begin{array}{l}\text { dorso-lateral apodemes of phallotheca } \\
\text { connected to ventral side of segment X }\end{array}$ & $\begin{array}{l}\text { dorso-lateral apodemes of phallotheca connect- } \\
\text { ed to apodemes of coxopodite }\end{array}$ \\
\hline 2 & tergal strap absent & tergal strap present \\
\hline 3 & $\begin{array}{l}\text { Dorsal process of phallotheca broad and } \\
\text { plate-like, fused basally with the phallothe- } \\
\text { cal, dorsal apodemes }\end{array}$ & $\begin{array}{l}\text { Dorsal process a slender extension of dorsal } \\
\text { roof of phallotheca }\end{array}$ \\
\hline 4 & Anal sclerites separate, without roots & Anal sclerites with roots \\
\hline 5 & aedeagus with bifid tip & aedeagus tube-like, with simple tip \\
\hline 6 & anal sclerites vestigial or absent & anal sclerites large, present \\
\hline
\end{tabular}

The castanea group has an extended range in South East Asia (Fig. 30) with many species but only one species, $R$. argentipunctella Kimmins, 1955, is known so far in Borneo. By contrast four species are described from the Philippines. They are closely related but live on different islands (Fig. 28). The ancestor of the Philippine species was a close relative of a group with $R$. argentipunctella as the only representative in Borneo. In the Pleistocene land-bridges developed and connected Borneo with Mindanao (Heaney 1985). Having arrived in Mindanao, probably along the Sulu Archipelago, the species was able to colonise southern Luzon and spread to northern Luzon. Even the Visayan Islands were reached with Negros as the hitherto only island with a species of this group ( $R$. negrosana Mey, 1998). Occurrence on other Visayan Islands like Panay or Cebu is very probable (Fig. 28). 
The spinosellata group consists of six species. The first described species of the group were assigned to the yosiiana-group. Interestingly, the group has no close relatives on Borneo, Sundaland and in South East Asia (cf. Malicky 2010) (Fig. 31). Rhyacophila brechlini MeY, 1998, a Vietnamese species, was originally placed in the yosiiana group. Reexamination of the holotype revealed that it was misplaced in the group. In fact the species exhibit the primitive coupling of coxopodite and phallotheca by apodemes and the presence of a long tergal strap. The phallotheca is not firmly connected with the ventral side of segment $\mathrm{X}$ - the synapomorphy of the spinosellata-, yosiiana- and betteni groups. The species is probably better placed in the scissa group. The origin of the spinosellata group appears to be somewhat enigmatic. A closer examination of the genital morphology revealed that the oldest evolutionary line is represented by R. amoyanensis sp. n., discovered on Palawan (Fig. 29). From a geological viewpoint Palawan does not belong to the Philippines, but is situated on the Sunda Shelf close to Borneo (Hall 1996). At the height of the Pleistocene Palawan, including the Busuanga Islands further north, formed an elongate extension on the north-east margin of the fully exposed Sundaland shelf. Though in a peripheral position, it received the full spectrum of the Sundaland fauna (Oosterzee 1997, Heaney et al. 1998). $R$. amoyanensis sp. $\mathrm{n}$. can be regarded as a Sundaland species. It is perhaps the surviving descendant of a more widespread species whose range extended through Borneo. Future fieldwork should clarify whether or not it is the only survivor. This ancestral Bornean species was able to spread over the exposed Sulu Archipelago and immigrated into Mindanao in accordance with the scenario described for the castanea group. Subsequent dispersion and speciation gave raise to different clades on the northern islands (Luzon, Mindoro) and on the southern islands (Negros, Mindanao) (Fig. 29).

Alternative scenarios of immigration pathways into the Philippines were discussed by MEY (1999). They are based on a presumed, extended range of the yosiiana group towards southern China. From there, the route of a pre-Pleistocene ancestor into the Philippines should have run via Taiwan or was mediated by Mindoro, a continental terrane shifted with the opening South China Sea to its present position on the west side of the Philippines. Supporting arguments for these hypotheses might be provided by the discovery of hitherto undetected ancestral species still occurring in southern China and Taiwan. Up to now, such species have not been found. The discovery of three new species in the Philippines does not render these hypotheses less plausible. In fact, all proposed hypothesis try to explain an apparently extinction-mediated distribution pattern. Support for any scenario can be provided only if the extinction was not complete and surviving species still can be found. In any case, the range of the spinosellata group is that of a relict group separated by wide disjunctions from related groups. It is restricted to the Philippine Islands, and this makes the Philippines 


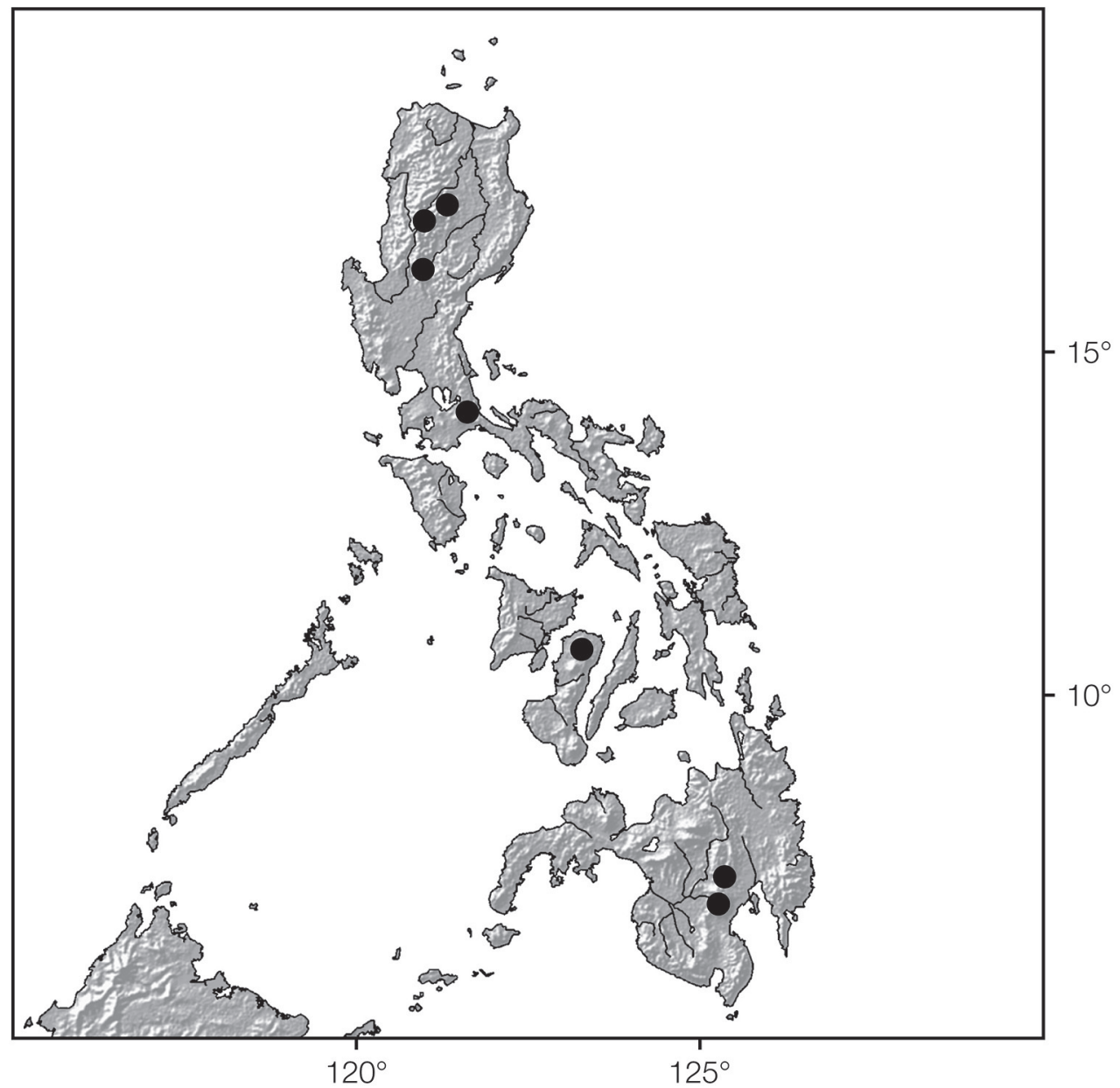

Fig. 27: Map of known localities of the castanea group in the Philippines.

an archipelago of refuge. There are probably additional groups in Trichoptera, and in other insect orders, for which the Philippines play the same role as a survival area. The search for additional relict groups is an exciting venture. The study of their phylogeny and biogeographic history might result in new arguments that can throw new light on the radiation of Rhyacophila and the herein presented attempt to find a plausible explanation.

\section{Acknowledgements}

I am sincerely grateful to Brian Armitage for reviewing the manuscript and discussing some details. Field work on Borneo and the Philippines was financially supported by the DFG (Me 1085/5-3, 1085/ 5-4). My thanks are also due to Venancio Samarita (National Museum Manila) for good company in the Philippines.

\section{References}

Broad, R. \& Cavanagh, J. 1993: Plundering Paradise. - University of California Press: VIII + 197 pp.

Cowie, R. H. \& Holland, B. S. 2006: Dispersal is fundamental to biogeography and the evolution of biodiversity on oceanic islands. - Journal of Biogeography 33: 193-198. 


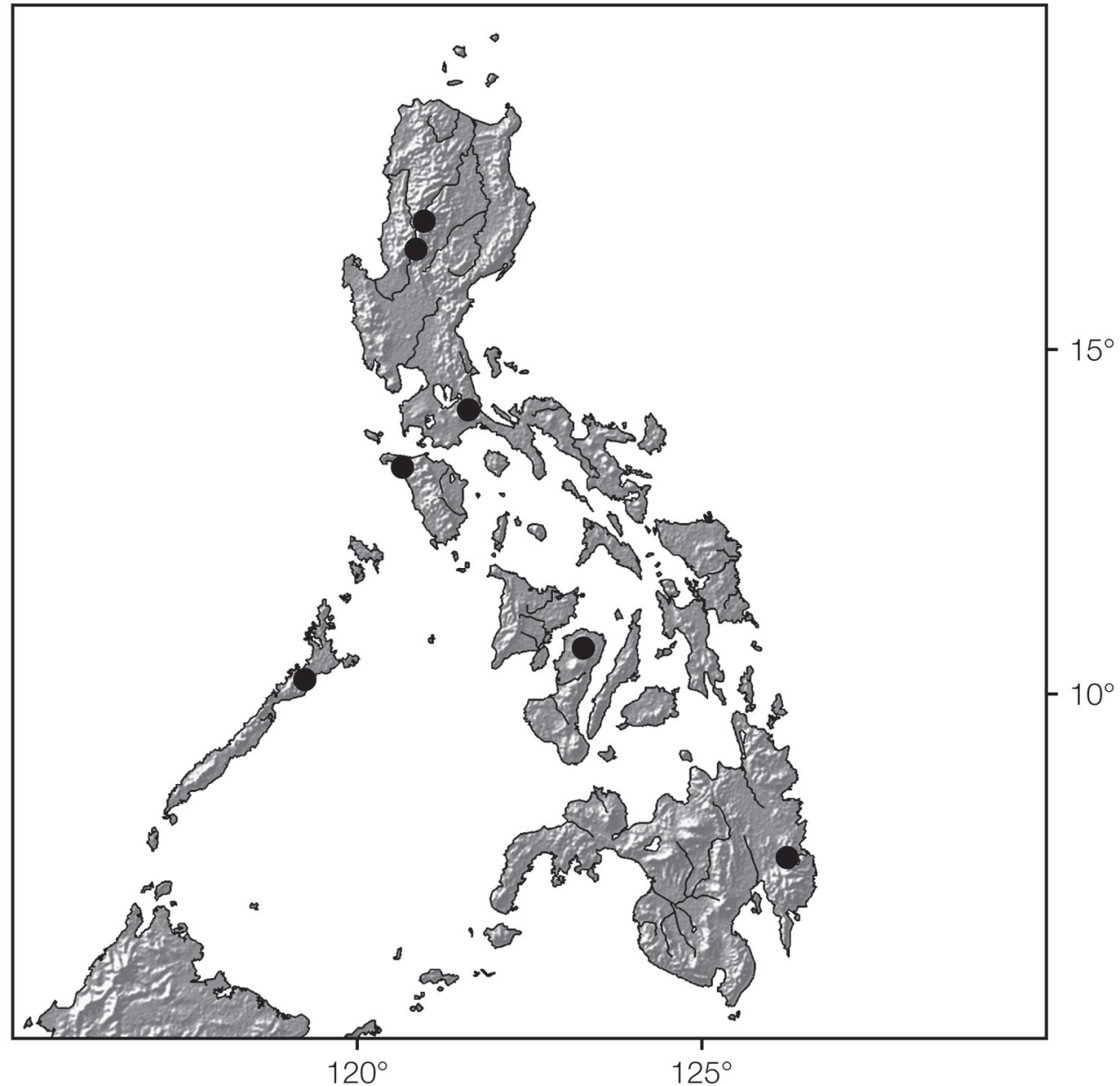

Fig. 28: Map of known localities of the spinosellata group in the Philippines.

Hall, R. 1996: Reconstructing Cenozoic SE Asia: pp. 153-184. - In: Hall, R. \& Blundell, D. (eds.): Tectonic evolution of Southeast Asia. Geological Society Special Publication No. 106: 566 pp.

Heaney, L. R. 1985: Zoogeographic evidence for Middle and Late Pleistocene land bridges to the Philippine Islands. - Modern Quarternary Research in SE Asia 9: 127-143.

Heaney, L. R.; Balete, D. S.; Dolar, M. L.; Alcala, A. C.; Dans, A. T. L.; Gonzales, P. C.; Ingle, N. R.; Lepiten, M. V.; Oliver, W. L. R.; Ong, P. S.; Rickart, E. A.; Tabaranza, B. R.; Utzurrum, R. C. B. Jr. 1998: A Synopsis of the mammalian fauna of the Philippine Islands. - Fieldiana Zoology N.S. 88: 1-61.

Heaney, L. R. \& Regalado, J. C. Jr. 1998: Vanishing treasures of the Philippine rain forest. - The Field Museum, Chicago: 88 pp.

Huisman, J. \& Armitage, B. 2011: Four new species of Rhyacophila (Trichoptera: Rhyacophilidae) from Sabah, East Malaysia. - Proceedings of the $13^{\text {th }}$ International Symposium on Trichoptera. - Zoosymposia 5: 147-157.

Jong, R. DE \& Treadaway, C. G. 1993: The Hesperiidae (Lepidoptera) of the Philippines. - Zoologische Verhandelingen, Leiden: 1-122.

Kovats, Z. E.; Сiвorowski, J. H. \& Corkum, L. D. 1996: Inland dispersal of adult aquatic insects. Freshwater Biology 36: 265-276. 


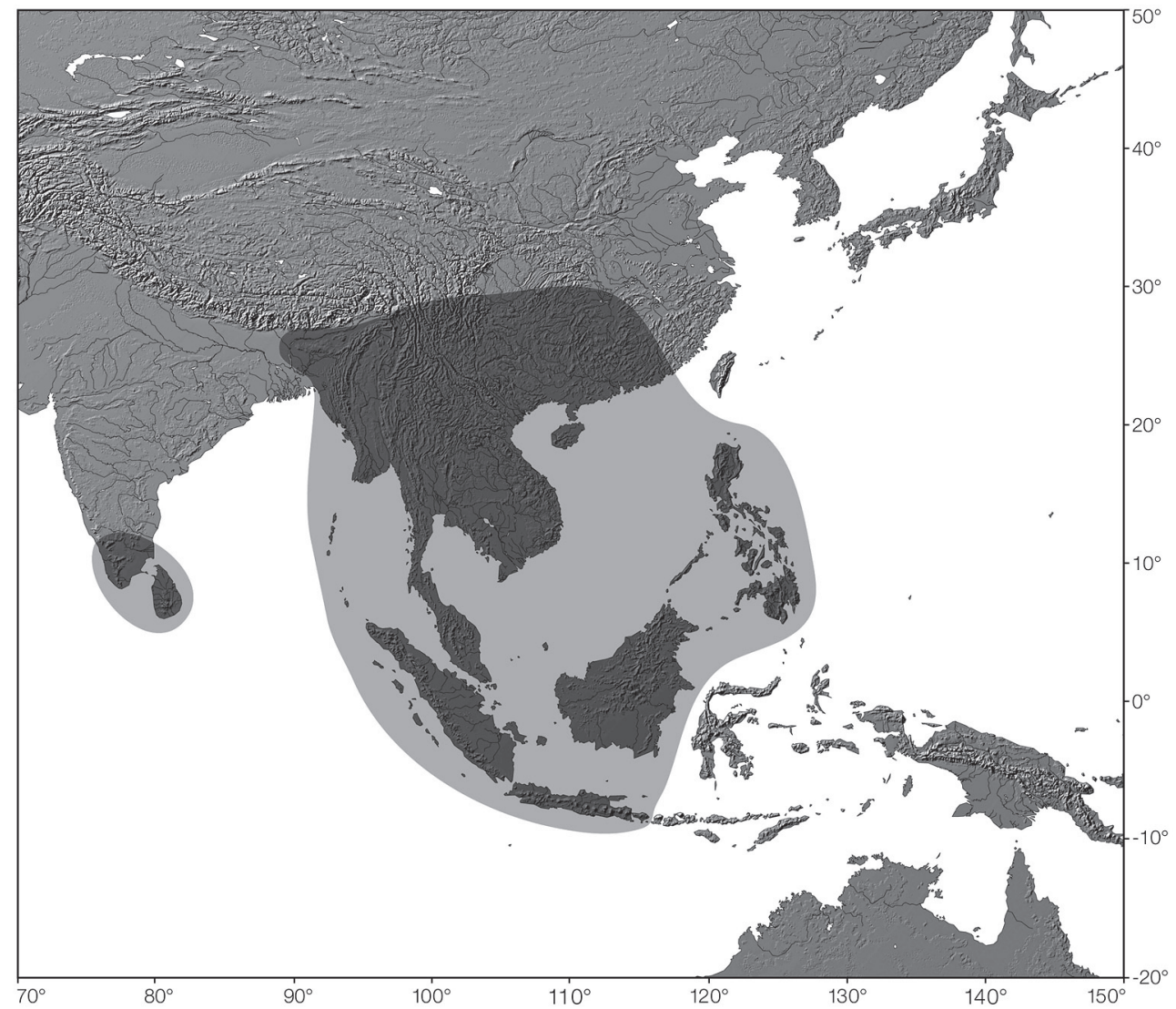

Fig. 29: Distribution map of the castanea group in Southeast Asia.

Malicky, H. 2010: Atlas of Southeast Asian Trichoptera. - Chiang Mai University, Chiang Mai, Thailand: XXX + 346 pp.

MeY, W. 1999: Origin an formation of the distributional patterns of Rhyacophila species in the islands of South-East Asia (Insecta, Trichoptera: Rhyacophilidae). - Senckenbergiana biologica 78: 193-203.

Mey, W. 2003: Insular radiation of the genus Hydropsyche Pictet, 1834 in the Philippines and its implications for the biogeography of SE Asia (Insecta, Trichoptera: Hydropsychidae). - Journal of Biogeography 30: 227-236.

Mey, W. 2010: New species of Apsilochorema Ulmer and Rhyacophila Pictet from northern Borneo, with a note on Rhyacophila isolata Banks (Insecta: Trichoptera). - Denisia 29: 201-214.

Morley, R. J. 2000: Origin and evolution of tropical rain forests. - John WILEY \& Sons, Chichester: XV $+362 \mathrm{pp}$.

Ross, H. H. 1956: Evolution and classification of the mountain caddisflies. - University of Illinois Press, Urbana: 213 pp.

Schmid, F. 1970: Le genre Rhyacophila et la famille de Rhyacophilidae (Trichoptera). - Memoires de la Société entomologique du Canada 66: 230 pp +52 pls.

Schmid, F. 1989: Les Hydrobiosides (Trichoptera, Annulipalpia). - Bulletin de l’institute Royal des sciences naturelles de Belgique, entomologie 59 supplement: 1-154.

Smith, J. M. B. 2001: Did early hominids cross sea gaps on natural rafts? - In: Metcalf, I.; Smith, J. M. B.; Morwood, M. \& Davidson I. (eds.): Faunal and floral migrations and evolution in SE Asia - Australasia. Balkema Publishers, Lisse: 417 pp. 


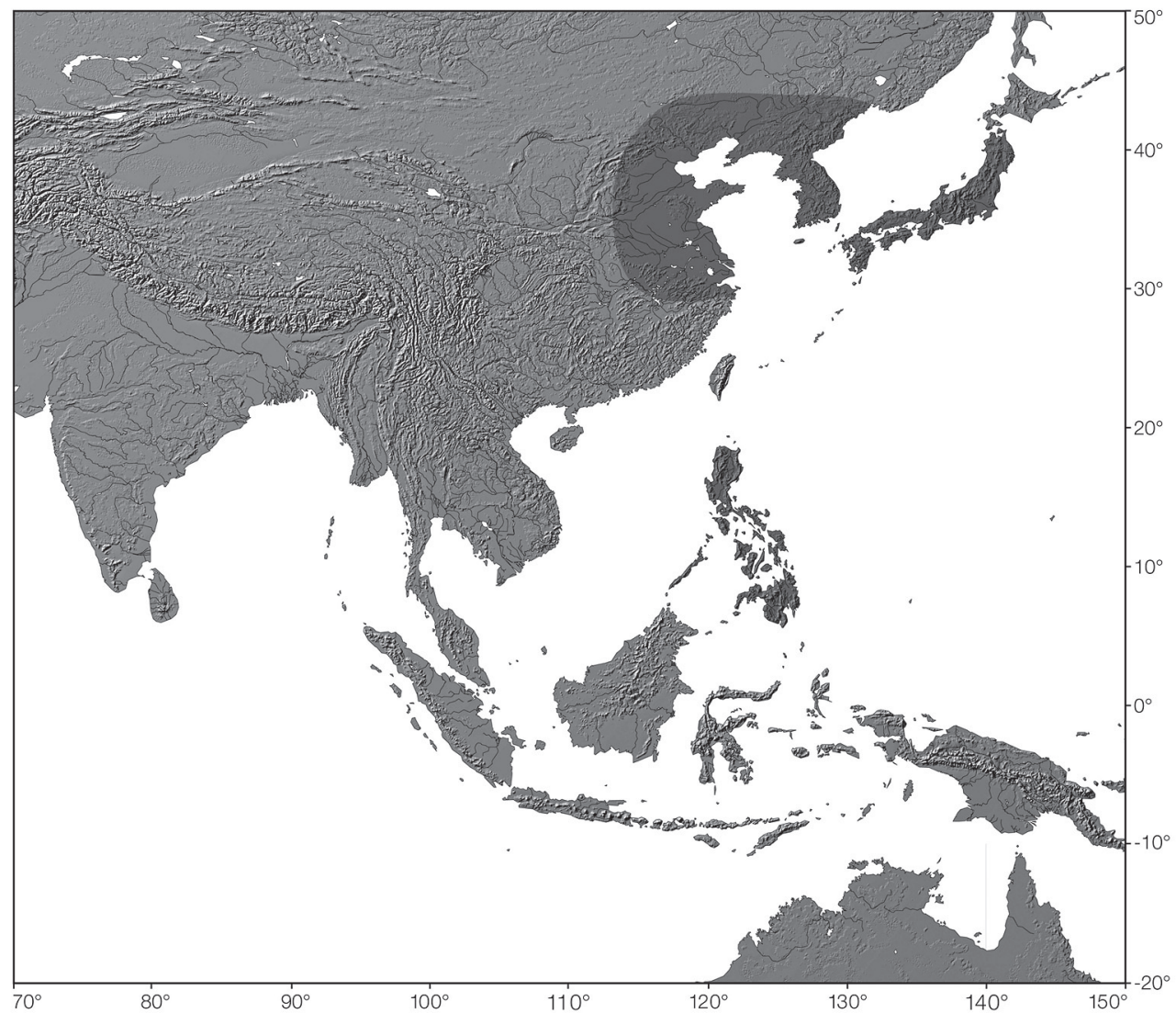

Fig. 30: Distribution map of the spinosellata group in East and Southeast Asia.

TAN, B. C.; Li Z.-H. \& Lin, P.-C. 1988: The Hainan-Mindoro connection, an obscure pathway for plant migration in Southeast Asia. - Natural History Bulletin of the Siam Society 36: 7-15.

Ulmer, G. 1912: Die Trichopteren des Baltischen Bersteins. - Beiträge zur Naturkunde Preussens 10: 380 pp.

Wallace, A. R. 1880: Island Life - Macmillan, London: 526 pp.

Wichard, W.; Gröhn, C. \& Seredszus, F. 2009: Aquatic Insects in Baltic Amber. - Verlag Kessel Rehmagen-Oberwinter: 335 pp.

Wirson, E. O. 1992: The diversity of life. - The Belknap Press of Harvard, University Press, Cambridge/ Massachusetts.

Author's address:

Dr. Wolfram Mey

Museum für Naturkunde

Leibniz Institut der Humboldt Universität

Invalidenstraße 43

10115 Berlin, Germany

e-mail: Wolfram.mey@mfn-berlin.de
Subject editor:

Dr. B. J. Armitage 